\title{
RESOLUSI KONFLIK PAKISTAN DAN INDIA DALAM PEREBUTAN WILAYAH KASHMIR DAN PELUANG MEDIATOR BAGI INDONESIA
}

\author{
Brilliant Windy Khairunnisa \\ Universitas Islam Negeri Sunan Ampel \\ brilliantwindyk@gmail.com
}

\begin{abstract}
Abstrak
Konflik yang terjadi antara Pakistan dan India pada perbatasan kedua negara dalam perebutan wilayah Kashmir telah berlangsung bertahun-tahun lamanya. Meski telah banyak upaya yang dicoba untuk mendamaikan kedua negara, namun konflik tetap berlanjut hingga banyak menimbulkan kerugian pada penduduk asli Kashmir yang berlangsung sampai saat ini. Sebagai negara yang memiliki hubungan baik dengan Pakistan dan India, Indonesia dapat dinyatakan sebagai negara yang bersifat netral dan memiliki peluang yang cukup besar untuk menjadi mediator kedua negara tersebut sebagai upaya resolusi konflik. Artikel ini bertujuan untuk membahas upaya-upaya dalam melakukan resolusi konflik antara Pakistan dan India dalam perebutan wilayah Kashmir serta peluang yang dimiliki Indonesia untuk menjadi mediator kedua negara tersebut. Metode penelitian menggunakan kualitatif eksploratif dan teknik pengumpulan data berupa studi pustaka yang berbasiskan data sekunder. Hasil penelitian menunjukkan adanya peluang yang dimiliki Indonesia untuk menjadi mediator dalam resolusi konflik Kashmir.
\end{abstract}

Kata Kunci: Resolusi konflik, konflik Pakistan-India, Kashmir, Indonesia, Mediator

\begin{abstract}
The conflict between Pakistan and India on the border of the two countries in the dispute over the Kashmir region has been going on for years. Although many efforts have been tried to reconcile the two countries, the conflict continues to cause a lot of harm to the indigenous people of Kashmir which continues to this day. As a country that has good relations with Pakistan and India, Indonesia can be declared as a neutral country and has a large enough opportunity to become a mediator between the two countries as a conflict resolution effort. This article aims to discuss the efforts to resolve the conflict between Pakistan and India in the dispute over the Kashmir region and the opportunities that Indonesia has to become a mediator between the two countries. The research method in this study uses exploratory qualitative and data collection techniques in the form of literature studies based on secondary data. The results of the study indicate that Indonesia has an opportunity to become a mediator in the resolution of the Kashmir conflict.

Keywords : Conflict Resolution, Pakistan-India Conflict, Kashmir, Indonesia, Mediator.
\end{abstract}

\section{Pendahuluan}

Sejak tahun kemerdekaannya pada 1947, negara Pakistan dan India terus memiliki hubungan yang kurang baik. Hal ini dapat dilihat dari adanya konflik bersenjata yang telah terjadi sebanyak empat kali sejak tahun kemerdekaannya hingga saat ini (Fajria, 2018). Adapun konflik tersebut terjadi disebabkan oleh adanya perebutan wilayah Kashmir yang terletak di antara kedua negara tersebut yang juga masih berlangsung hingga saat ini. Konflik perebutan Kashmir antara Pakistan dan India ini semakin memanas dengan adanya keputusan Perdana Menteri India, Narendra Modi yang mulai mencabut pasal 370 dari UndangUndang India yang berisi tentang adanya hak istimewa bagi wilayah Kashmir pada 
tahun 2019 lalu. Sebab dengan adanya kebijakan tersebut, wilayah Kashmir akan kehilangan hak otonominya serta dapat menyebabkan adanya warga negara India yang dapat membeli tanah di wilayah Kashmir tanpa batas, yang mana sebelumnya merupakan suatu pelanggaran (Rosdiana, 2020). Kebijakan ini pula menjadi pertentangan bagi Pakistan, sebab mayoritas warga Kashmir memiliki kesamaan ideologi dengannya, yaitu beragama Islam.

Adanya kebijakan baru tersebut, memunculkan kekhawatiran akan terputusnya hubungan bilateral antara Pakistan dan India, khususnya dalam bidang perdagangan dan ekonomi. Konflik yang terus berlanjut tersebut juga menyebabkan adanya kegentingan bagi negara-negara di kawasan Asia pada umumnya, dan negara-negara di kawasan Asia Selatan khususnya (Noer Aieni, 2017). Hal ini disebabkan oleh adanya kekuatan militer yang telah dimiliki oleh kedua negara dengan kapasitas nuklir yang memadai sehingga diperkirakan akan memunculkan kehancuran dunia apabila peperangan terjadi di antara kedua negara. Yang mana, kedua negara ini telah beberapa kali melakukan uji coba nuklir yang terakhir kali terjadi pada awal Januari 2020 lalu dimana hal ini dapat dikatakan sebagai upaya bandwagoning menurut perspektif realis (Hervi, 2019). Usaha untuk mendamaikan kedua negara kembali dilakukan oleh South Asian Association for Regional Cooperation (SAARC) yang merupakan organisasi regional di Asia Selatan dengan cara melakukan KTT SAARC setiap tahunnya sejak tahun 1985. Namun hingga pada pertemuan ke-14 tahun 2007, konflik antara kedua negara kembali memanas sebab adanya tuduhan India terhadap Pakistan yang melakukan serangan ke Mumbai di India (Aisy, 2015).

Upaya untuk mendamaikan kedua negara tersebut kembali dilakukan dengan adanya Presiden Amerika Serikat, Donald Trump yang menawarkan diri untuk memediasi kedua negara. Meski pada akhirnya, upaya tersebut belum dapat diterima dengan baik oleh pihak India sebab dikhawatirkan akan adanya keberpihakan yang akan dilakukan olehnya serta adanya kepentingan nasional India yang dapat terhalangi apabila Amerika Serikat menjadi mediator dalam resolusi konflik perebutan wilayah Kashmir tersebut (Ahmad, 2019). Adapun desakan perdamaian telah banyak dilakukan oleh beberapa pihak internasional sebab konflik antara Pakistan dan India dalam perebutan Kashmir tidak hanya menimbulkan kerugian secara ekonomi, melainkan juga melibatkan kasus agama dan kemanusiaan, dimana konflik ini setidaknya telah menjatuhkan ribuan korban selama lebih dari tujuh dekade, baik dari warga sipil maupun dari anggota militer itu sendiri.

Di sisi lain, pada dasarnya upaya dalam mendamaikan Pakistan dan India terhadap perebutan kepemilikan wilayah Kashmir sebelumnya telah dilakukan oleh Persatuan Bangsa-Bangsa (PBB) sejak awal kemerdekaaannya. Dimana PBB telah melakukan berbagai macam cara untuk memenuhi tujuan dibentuknya yaitu menjaga perdamaian di dunia, dimana usaha tersebut sempat melemah dengan pernyataan bahwa permasalahan antara Pakistan dan India harus diselesaikan terlebih dahulu secara bilateral pada resolusi tahun 1964 (Effendi, 2005). Meski demikian, konflik yang terus berlanjut hingga saat ini dapat membuktikan bahwa upaya bernegosiasi antara kedua negara dalam mencapai perdamaian belum dapat terlaksana dengan baik. Adapun usaha lain yang dapat dilakukan untuk mencapai 
perdamaian antara kedua negara apabila proses negosiasi kedua belah pihak belum dapat berjalan dengan baik, yaitu dengan melibatkan pihak ketiga sebagai penengah konflik antara kedua negara (Horne, 2013).

Hal ini disebabkan oleh adanya kekhawatiran akan adanya keberpihakan saat berlangsungnya proses mediasi apabila mediator tidak bersifat netral terhadap kedua negara tersebut. Adapun organisasi internasional PBB telah dinilai masih memiliki posisi yang kuat untuk menjadi mediator sebagai upaya dalam mendamaikan Pakistan dan India dalam resolusi konflik perebutan Kashmir. Sedangkan Dewan Keamanan PBB, merupakan pengampu tugas dalam mencapai perdamaian konflik tersebut (Danial, 2010).

Sejak bulan Agustus 2020, Indonesia kembali dilantik menjadi presiden Dewan Keamanan PBB. Dengan posisi ini, Indonesia memiliki beban tanggung jawab untuk melanjutkan upaya-upaya yang telah dilakukan oleh PBB sebelumnya dalam mewujudkan keamanan dunia, khususnya perihal konflik perebutan Kashmir tersebut. Mediasi transformative dapat dilakukan oleh negara Indonesia terlebih atas jabatan barunya tersebut yang mana bertujuan untuk memperbaiki dan menyelesaikan hubungan antara kedua negara berkonflik usai terjadinya sengketa (Sugianto, Simeon, \& Wibowo, 2020). Hal ini juga dapat didukung dengan adanya hubungan antara Indonesia dengan Pakistan serta India yang dinilai cukup baik dan dapat dikatakan sebagai negara yang netral untuk menengahi perselisihan antara kedua negara tersebut.

Berdasarkan pemaparan permasalahan di atas, penelitian ini bertujuan untuk membahas lebih detail terkait upaya-upaya penyelesaian konflik antara Pakistan dan India yang telah dilakukan terhadap perebutan wilayah Kashmir yang berkepanjangan serta untuk menjawab apakah terdapat peluang yang dimiliki oleh Indonesia sebagai mediator dalam resolusi konflik tersebut. Adapun analisa penelitian yang akan digunakan, ialah dengan menggunakan pendekatan multidisiplin.

Terdapat pengembangan hipotesa penelitian yang ditemukan melalui tinjauan pustaka, dimana tinjauan pertama memaparkan tentang kontribusi yang telah dilakukan Persatuan Bangsa-Bangsa (PBB) dalam menangani konflik bersenjata antara Pakistan dan India dalam perebutan kekuasaan Kashmir pada periode 20112013 (Rizky, 2016). Atas persetujuan kedua negara, PBB menjadi mediator nonnegara yang bersifat netral dalam menyelesaikan konflik Kasmir, dan telah mengajukan referendum. Namun demikian, pengajuan referendum tersebut belum ditindaklanjuti oleh kedua negara hingga terjadi konflik bersenjata kembali pada tahun 2013 serta adanya konflik perebutan wilayah yang masih terus berlanjut hingga saat ini bahkan telah dilakukannya uji coba nuklir oleh negara Pakistan dan India pada awal 2020 lalu.

Tinjauan berikutnya peneliti menemukan adanya sengketa perebutan wilayah Kashmir melalui pandangan hukum internasional yang berlaku. Penelitian tersebut, telah menjelaskan terkait tingkat pelanggaran hukum internasional yang telah terjadi antara negara Pakistan dan India, dimana kedua negara tersebut telah ditengahi pula oleh organisasi kawasan Asia Selatan, The South Asian Association for Regional Cooperation (SAARC) dan telah ditinjau dari segi ekonomi dan sosial (Aisy, 2015; Alhayyan, 2012). Namun demikian, usaha tersebut belum 
terealisasikan dengan baik hingga belum memberikan dampak yang cukup signifikan terhadap penyelesaian konflik antara kedua negara. Adapun upaya mediasi dari pihak Amerika Serikat telah dilakukan, namun mendapatkan penolakan dari pihak India yang merupakan salah satu pihak berkonflik (Ahmad, 2019).

Berkaitan dengan tinjauan-tinjauan pustaka yang telah ditemukan oleh penulis, ditemukan adanya novelty atau kebaruan dalam penelitian ini. Dimana penelitian yang penulis lakukan berfokus pada upaya-upaya resolusi konflik antara Pakistan dan India dalam perebutan wilayah Kashmir secara menyeluruh. Adapun penelitian terkait peluang yang dimiliki oleh Indonesia untuk menjadi mediator dalam upaya resolusi konflik perebutan Kashmir melalui jabatannya sebagai Dewan Keamanan PBB, yang mana belum ditemukan penelitian serupa pada hasil penelitian-penelitian sebelumnya. Di sisi lain, hal tersebut dapat diperkuat dengan adanya kedekatan Indonesia terhadap negara Pakistan dan India yang terbilang sama, sehingga Indonesia dapat menjadi pihak netral untuk mendamaikan kedua negara melalui konsep resolusi konflik.

\section{Metode Penelitian}

Penelitian ini menggunakan metode penelitian kualitatif eksploratif yang menggambarkan hasil penelitian tanpa adanya statistika atau angka-angka. Datadata diperoleh melalui adanya observasi, wawancara pada beberapa sumber tertentu yang paham akan objek penelitian, serta melakukan adanya studi literatur dari penelitian ataupun dokumen-dokumen yang telah ada sebelumnya (Farr, 2008; Soendari, 2006). Adapun data-data tersebut didapatkan dalam bentuk kualitatif berbasiskan data sekunder, kemudian dianalisis dan dibantu oleh adanya teori dan konsep yang digunakan dalam penelitian ini sehingga dapat memperoleh hasil penelitian yang jelas. Di sisi lain, pengujian validitas data dilakukan menggunakan metode triangulasi, serta dilakukan adanya diskusi lanjutan (peer debriefing) dengan para akademisi.

\section{Hasil dan Pembahasan}

\section{Mediasi dalam Diplomasi}

Pelibatan pihak ketiga sebagai penengah konflik internasional atau yang biasa disebut sebagai mediasi, dapat dilakukan melalui pendekatan resolusi konflik dimana mediator dapat berasal dari kalangan negara yang bersifat netral terhadap kedua negara berkonflik, ataupun melalui organisasi-organisasi internasional yang juga bersifat netral terhadap kedua negara (Chan, 2017). Sifat netral pada mediator merupakan salah satu hal terpenting yang harus dimilikinya untuk menghindari adanya ketidakadilan dalam pencapaian resolusi konflik yang mana keputusan akhir tetap berada di tangan kedua pihak bersengketa. Dengan kata lain, seorang mediator tidak memiliki hak untuk memberikan keputusan, melainkan membantu kedua pihak bersengketa untuk memutuskan resolusi yang terbaik dan dapat diterima oleh kedua belah pihak. Dalam hal ini, Laurence Boulle menyatakan beberapa peran yang dimiliki oleh mediator dalam melakukan mediasi pada resolusi konflik di antaranya mewujudkan rasa percaya dari kedua belah pihak berkonflik 
terhadapnya, melakukan analisa mendalam terhadap konflik yang sedang terjadi, memberikan fasilitas untuk melakukan diskusi dalam menyelesaikan masalah yang ada terhadap pihak berkonflik, melakukan promosi terkait realitas dan komunikasi yang bersifat konstruktif, memberikan bimbingan terhadap pihak berkonflik, memberikan motivasi pada pihak berkonflik untuk mengakhiri konflik yang terjadi, serta menyarankan dan mengevaluasi (Oktarezki, 2021).

Dengan demikian, dapat dinyatakan bahwa seorang mediator memiliki peran utama sejak awal dimulainya proses resolusi konflik dan mediasi dapat diakhiri apabila keputusan akhir telah dikeluarkan oleh kedua pihak berkonflik. Adapun hasil akhir yang dapat diperoleh oleh pihak berkonflik dari mediasi ialah win-win sehingga tidak ada pihak yang dirugikan. Namun demikian, adanya peranperan yang dimiliki mediator dalam resolusi konflik pada era digitalisasi juga memiliki tantangan yang cukup besar sebab akan terdapat intervensi media yang dapat memperburuk konflik yang sedang terjadi sehingga mediator harus dapat memiliki keseimbangan dan kepandaian dalam mendapatkan kabar benar terkait konflik yang sedang terjadi (Khairunnisa, 2021). Di sisi lain, peran mediator sebagai pihak ketiga yang bersifat netral tersebut pada akhirnya menyebabkan pemilihan mediator seringkali berdasarkan pengaruh kuat yang dimiliki olehnya terhadap para pihak berkonflik (Suwandono, 2018).

\section{Penyebab Konflik Perebutan Kashmir}

Dari segi historis, konflik yang terjadi antara Pakistan dan India dalam perebutan wilayah Kashmir berawal saat kolonialisme Inggris membagi negara India menjadi dua bagian, India dengan penduduk mayoritas beragama Hindu dan Pakistan dengan penduduk Muslim terbanyak. Namun demikian, pembagian negara tersebut meninggalkan kepemilikan wilayah Kashmir. Dengan demikian, wilayah tanpa pemilik tersebut menyebabkan adanya perebutan dari negara Pakistan dan India hingga terjadinya konflik dan peperangan hingga saat ini (Ayunda, 2017). Dalam hal ini, konflik perebutan wilayah terus terjadi sebab adanya masyarakat Kashmir yang mayoritas beragama Islam namun memiliki pemimpin yang beragama Hindu. Dimana hal tersebut memunculkan tidak hanya konflik perebutan wilayah, melainkan juga melibatkan adanya konflik berbasiskan identitas agama dan kemanusiaan (Fauzi, Sari, \& Rachmat, 2016; Raharjo, 2015).

Di samping adanya identitas agama yang menjadi salah satu penyebab terjadinya konflik antara Pakistan dan India, keadaan wilayah Kashmir juga menjadi salah satu penyebab terjadinya perebutan tersebut. Dimana wilayah Kashmir memiliki sumber daya alam yang kaya dengan adanya tanah yang subur dan pembangunan pedesaan yang terus mengalami perkembangan (Ahmad Sheikh, 2018). Adapun beberapa aliran sungai yang bermuara dari wilayah Kashmir menuju kawasan Pakistan dan India, telah menjadikan lahan pertanian pada kedua negara tersebut bergantung terhadapnya (Azlan, Nasrin, \& Ali, 2017). Di sisi lain, keindahan alam yang dimiliki oleh wilayah Kashmir dapat menarik banyak sekali wisatawan hingga kancah internasional. Dengan demikian, adanya sumber daya 
alam yang melimpah dan indah di wilayah Kashmir dapat dianalisa sebagai salah satu penyebab terjadinya sengketa perebutan tersebut.

Di sisi lain, adanya konsep kepentingan nasional telah menjadi salah satu hal yang sangat penting dalam mengeluarkan kebijakan luar negeri. Sebab pada dasarnya, keberhasilan suatu negara dalam mencapai tujuannya sangat bergantung pada kebijakan yang dikeluarkannya (Dermawan, 2020). Dengan demikian, adanya konflik dalam perebutan Kashmir dapat dianalisa sebagai salah satu cara yang dimiliki oleh Pakistan dan India dalam menggapai kepentingan nasionalnya masing-masing. Dimana kepentingan tersebut dapat tercapai apabila wilayah Kashmir berhasil dikuasai. Sebagaimana sumber daya alam yang indah dan kaya yang dimiliki oleh wilayah Kashmir, kekayaan alam tersebut dapat menjadi sumber perekonomian yang besar bagi negara. Baik dari segi pariwisata yang dapat mendatangkan wisatawan lokal ataupun asing, pertanian, ataupun dari segi perkebunan sekalipun. Dimana keberadaan wisatawan dari mancanegara tersebut dapat mempermudah dan mempererat adanya kerjasama atau diplomasi yang terjalin dengan negara-negara lainnya (Carbone, 2017). Sebab pada dasarnya, kawasan pariwisata telah menjadi sektor yang cukup penting dalam mengembangkan perekonomian suatu negara (Sudirman, Sarma, \& Susilawaty, 2020).

\section{Upaya Resolusi Konflik Kashmir}

Adanya periode yang berlangsung cukup lama dalam perebutan Kashmir juga telah melibatkan beberapa pihak dalam upaya resolusi konflik. Hal ini disebabkan oleh adanya ancaman nasional yang dimiliki oleh negara-negara di kawasan Asia Selatan apabila Pakistan dan India terus bersengketa hingga terjadinya peperangan. Sebab pada dasarnya, kedua negara tersebut merupakan negara yang memiliki pengaruh besar di kawasan Asia Selatan (Nugroho, 2017). Dalam hal ini, PBB dengan perdamaian dunia sebagai salah satu tujuan didirikannya memiliki peran yang cukup besar sebagai mediator dalam upaya resolusi konflik di Kashmir. Dimana PBB telah mengeluarkan resolusi pada tahun 1948 serta 1949 yang mendukung adanya kemerdekaan bagi wilayah Kashmir. Namun demikian, resolusi PBB tersebut dapat dianalisa telah gagal memperoleh kedamaian antara Pakistan dan India dalam sengketanya (Wani \& Suwirta, 2014). Hal ini diperkuat dengan adanya sengketa yang terus berlangsung antara kedua negara, baik secara langsung ataupun secara bandwagoning dalam perspektif realisme (Hervi, 2019).

Selain adanya upaya mediasi resolusi konflik yang dilakukan oleh organisasi internasional PBB, upaya tersebut juga dilakukan oleh organisasi internasional kawasan Asia Selatan SAARC yang mana fokus dalam bidang ekonomi dan politik di kawasan tersebut. Sebab pada dasarnya, adanya konflik antara dua kekuatan besar di kawasan sebagaimana Pakistan dan India telah menjadikan ekonomi dan politik di kawasan Asia Selatan juga terancam. Adapun dalam upaya resolusi konflik tersebut, SAARC mengalami tantangan berupa adanya keterlibatan negara-negara lain sebagaimana Amerika Serikat, Soviet dan 
Cina dalam pelaksanaan mediasi tersebut. Hingga pada KTT SAARC tahun 2004, organisasi kawasan tersebut berhasil memunculkan kesepakatan pada Pakistan dan India untuk menyelesaikan konflik Kashmir dengan adanya pertemuan dan negosiasi lanjutan pada pertemuan berikutnya (Aisy, 2015). Namun demikian, adanya upaya resolusi konflik tersebut hanya bersifat sementara. Dimana hal ini dapat dianalisa dengan adanya konflik lanjutan yang terjadi antara Pakistan dan India dalam perebutan Kashmir. Adapun hal tersebut terjadi sebab adanya kepentingan-kepentingan nasional lainnya yang belum diperoleh oleh kedua negara tersebut.

Di sisi lain, upaya resolusi konflik telah dilakukan dengan adanya diplomasi publik oleh pekerja seni pada tahun 2015 melalui media film Bajrangi Bhaijaan. Dimana film tersebut menjadi media yang mengungkapkan adanya perdamaian antara negara Pakistan dan India serta adanya toleransi beragama yang baik khususnya antara Islam dan Hindu dimana kedua agama tersebut telah menjadi agama mayoritas pada kedua negara berkonflik tersebut. Adapun dalam upaya diplomasi publik, berbagai macam media komunikasi digunakan untuk mendukung tersebarnya film tersebut pada kancah internasional. Dalam hal ini, nilai-nilai perdamaian antara Pakistan dan India berhasil diperluas dengan baik pada tingkat nasional, regional ataupun internasional (Lutfiyana, 2018; Sitepu, 2017). Dimana hal tersebut dianalisa dengan adanya ulasan-ulasan serta penelitian-penelitian yang mengindikasikan adanya sisi baik dan keberhasilan dari film tersebut khususnya dari segi diplomasi antara dua negara.

Adapun upaya lain dalam resolusi konflik dilakukan oleh Amerika Serikat pada masa kepemimpinan presiden Donald Trump di tahun 2017, dimana upaya mediasi ditawarkan oleh duta besar Amerika Serikat. Namun demikian, upaya mediasi tersebut mendapatkan penolakan dari India sebagai pihak berkonflik hingga mediasi mengalami kegagalan untuk mendamaikan kedua negara. Sebab pada dasarnya, medisi dapat dilakukan apabila kedua pihak berkonflik menyetujui adanya mediator tersebut (Alhayyan, 2012). Adapun di sisi lain, pihak Pakistan menyetujui Amerika Serikat sebagai mediator dalam resolusi konflik tersebut. Dalam hal ini, terdapat beberapa penyebab penolakan yang dilakukan oleh pihak India untuk menjadikan Amerika Serikat sebagai mediator. Dimana India ingin mempertahankan Kashmir sebagai konflik internal sebab wilayahnya terdapat pada bagian teritorial India, serta adanya keraguan dari pihak India terhadap pihak Amerika Serikat yang memiliki kepentingan lebih pada Pakistan (Ahmad, 2019). Adanya kepentingan lebih tersebut dapat menyebabkan adanya kecenderungan dalam mengambil keputusan dari pihak mediator pada saat mediasi berlangsung. Hal ini diperkuat dengan adanya kepentingan nasional Amerika Serikat di Pakistan dalam menjaga pertahanan dari terorisme, serta adanya pertahanan dari ideologi komunis di kawasan Asia Selatan (Fauzi et al., 2016). Dimana ideologi komunis yang di bawah Uni Soviet pernah membantu India dalam pasokan senjata nuklir pada tahun 1984 yang menambah adanya ancaman keamanan kawasan (Dewi, 2006). Meski pada dasarnya, kerjasama ekonomi yang terjalin antara Amerika Serikat dan Pakistan memiliki kekuatan yang hampir seimbang dengan India. 


\section{Peluang Indonesia Menjadi Mediator Resolusi Konflik}

Meski telah dilakukan beberapa upaya dalam resolusi konflik antara Pakistan dan India, ternyata belum memberikan hasil perdamaian di antara kedua negara dalam perebutan Kashmir. Hal ini menyebabkan adanya keamanan internasional yang semakin terancam diikuti dengan adanya pencabutan hak otonomi masyarakat Kashmir oleh Narendra Modi yang menyebabkan semakin panasnya konflik. Dalam hal ini, Indonesia dengan jabatannya sebagai Dewan Keamanan PBB sejak tahun 2019 berkontribusi dalam upaya stabilitas dan perdamaian global dengan pembuatan press statement perdamaian yang merupakan bagian dari mekanisme diplomasi pada Dewan Keamanan PBB. Adapun hal tersebut dapat dilakukan dengan melakukan resolusi konflik dan dialog ataupun negosiasi untuk mewujudkan perdamaian di dunia global. Adapun prinsip yang diterapkan dalam jabatannya tersebut, Indonesia merujuk pada UUD tahun 1945 serta pancasila yang mengedepankan adanya perdamaian dan mendukung hak asasi manusia di dunia. Di sisi lain, upaya-upaya dalam resolusi konflik dilakukan sesuai dengan fungsi dan wewenang yang dimiliki Dewan Keamanan PBB berupa memelihara keamanan dan perdamaian internasional sebagaimana yang tercantumkan dalam Piagam PBB Pasal 24 (KEMLU, 2019).

Selain dipandang dari adanya kedudukan Indonesia sebagai Dewan Keamanan PBB sejak tahun 2019, peluang yang dimiliki Indonesia untuk menjadi mediator dalam resolusi konflik Kashmir juga dapat dilihat dari segi hubungan diplomatik antara Indonesia dan kedua negara berkonflik tersebut. Dimana hal ini dilihat untuk memperkuat adanya peluang mediator, hingga kedua negara berkonflik menyetujui adanya mediasi sebagai resolusi konflik (Horne, 2013). Indonesia memiliki hubungan yang kuat dengan India khususnya di bidang perekonomian serta pertahanan laut. Dalam bidang perekonomian, hubungan Indonesia dan India diperkuat dengan adanya kerjasama lanjutan terkait ekspor minyak kelapa sawit di India (Ingpraja, 2020). Adapun dari segi kerjasama pertahanan laut dengan India telah terjalin sejak tahun 2000 hingga menghasilnya kesepakatan-kesepakatan baru terkait pertahanan laut dan telah memberikan dampak yang baik bagi kedua negara terlebih sejak adanya program JDCC yang disepakati (Rasyid, 2020). Dengan demikian, Indonesia dianalisa memiliki hubungan yang kuat dengan India dan memiliki peluang untuk mendapatkan persetujuan menjadi mediator dari pihak berkonflik tersebut.

Adapun pandangan dari hubungan antara Indonesia dan Pakistan sebagai pihak kedua yang berkonflik, juga memiliki kerjasama yang kuat khususnya di bidang ekonomi dan perdagangan. Hal ini dianalisa dari adanya kerjasama perdagangan yang dilakukan oleh Indonesia dan Pakistan yang diawali dengan adanya penandatangan perjanjian perdagangan preferensial atau PTA oleh Indonesia. Dimana perdagangan internasional telah menjadi kegiatan perekonomian yang semakin pesat perkembangannya untuk mencapai adanya kemudahan dalam bertransaksi (Hafiz, 2020). Adapun hubungan diplomatik tersebut kembali diperkuat dengan adanya diplomasi perdagangan yang dilakukan oleh Indonesia terhadap Pakistan melalui minyak kelapa sawit yang terus 
mengalami peningkatan dalam kerjasamanya (Hibatullah \& Nashir, 2021). Di sisi lain, kerjasama dalam bidang kelapa sawit juga dilakukan oleh Indonesia terhadap India yang dapat dianalisa sebagai kedua negara yang memiliki potensi lebih dalam hal pemasaran. Adapun dengan demikian, ketersalingan dalam kerjasama antara Indonesia dengan Pakistan dan India dapat dianalisa sebagai suatu kekuatan yang dapat memberikan peluang bagi Indonesia dalam upaya resolusi konflik Kashmir sebagai mediator.

\section{Simpulan}

Adanya kepentingan nasional yang dimiliki oleh Pakistan dan India menjadi salah satu penyebab terjadinya konflik Kashmir yang belum terselesaikan meski telah terdapat beberapa upaya resolusi konflik dari beberapa pihak. Adapun konflik tersebut telah menimbulkan ancaman yang besar khususnya di kawasan Asia Selatan. Di sisi lain, adanya jabatan Indonesia sebagai Dewan Keamanan PBB serta hubungan diplomatik yang kuat dengan kedua negara berkonflik dapat menjadikan Indonesia berpotensi untuk menjadi mediator dalam resolusi konflik tersebut. Namun demikian, adanya perlibatan agama dalam konflik Kashmir juga dapat menjadi penghalang adanya potensi Indonesia dalam mendamaikan kedua negara. Sebab pada dasarnya, Indonesia merupakan negara dengan mayoritas masyarakat beragama Islam dan Pakistan sebagai salah satu pihak berkonflik juga merupakan negara Islam. Dengan demikian, adanya peluang bagi Indonesia sebagai mediator konflik Kashmir memerlukan adanya aksi lanjutan baik dari segi penelitian ataupun dari segi kebijakan luar negeri dengan pemberian tawaran terhadap kedua negara berkonflik untuk menjadikan Indonesia sebagai mediator dengan upaya mencapai resolusi konflik. 


\section{Daftar Pustaka}

Ahmad, Adinda Nur Layla. (2019). Analisis Penolakan India Terhadap Amerika Serikat Sebagai Mediator Konflik Kashmir Tahun 2017. UIN Syarif Hidayatullah.

Ahmad Sheikh, Younis. (2018). Implementation of rural development programmes in Jammu and Kashmir. Journal of Governance and Public Policy, 5(1). https://doi.org/10.18196/jgpp.5191

Aisy, Andi Sitti Rohadatul. (2015). Peran Organisasi Internasional dalam Menangani Konflik Regional Studi Kasus : SAARC ( South Asian Association for Regional Cooperation ) dalam Konflik India dan Pakistan. 1-7.

Alhayyan, Riadhi. (2012). Sengketa Perbatasan Wilayah Kashmir Dalam Perspektif Hukum Internasional. Journal of International Law, 1(3), 1-18.

Ayunda, Monica Krisna. (2017). Konflik India dan Pakistan Mengenai Wilayah Kashmir Beserta Dampaknya (1947-1970). Risalah, 4(6), 911-925.

Azlan, Azrul, Nasrin, Mohamad, \& Ali, Mohd. (2017). Konflik Air Di Wilayah Kashmir Antara India Dan Pakistan Berdasarkan Perspektif Geo-Ekonomi. Universiti Kebangsaan Malaysia, 2(2), 137-153. Retrieved from https://minio1.123dok.com/id123dok/pdf/2018/11_29/154345983810326406 05_pdf.pdf?X-Amz-Content-Sha256=UNSIGNED-PAYLOAD\&X-AmzAlgorithm=AWS4-HMAC-SHA256\&X-AmzCredential=HBT28R878GBP52A279VA\%2F20190825\%2F\%2Fs3\%2Faws4 _request\&X-Amz-Date $=20190825 T 150617 Z \& X-A m z$

Carbone, Fabio. (2017). International Tourism and Cultural Diplomacy: A New Conceptual Approach Towards Global Mutual Understanding and Peace Through Tourism. Tourism, 65(1), 61-74.

Chan, Stephen. (2017). Meditations on Diplomacy: Comparative Cases in Diplomatic Practice and Foreign Policy. International Relations Publishing.

Danial. (2010). Peranan Dewan Keamanan Perserikatan Bangsa-Bangsa dalam Proses Penyelesaian Konflik Internasional. Jurnal Ilmu Dan Budaya, 32(23), 2328-2341.

Dermawan, Rifki. (2020). the National Interest Concept in a Globalised. Indonesian Journal of International Relations, (Vol.3 No.2 (2019)), 30-45. https://doi.org/https://doi.org/10.32787/ijir.v3i2.101

Dewi, Ita Mutiara. (2006). Dilema Masalah Kashmir dalam Kerangka Hubungan India-Pakistan. MOZAIK, 1(1), 1-14.

Effendi, Irmawan. (2005). Kashmir dalam Hubungan India-Pakistan: Perspektif Kebijakan Nuklir Pakistan, Latar belakang dan Perkembangan menuju 
Penyelesaian Konflik. Jurnal Siklus, Vol.1 No.3(ISSN 0216-5635), 3.

Fajria, Rayhana. (2018). Menilai Potensi Perang dibalik Kepemilikan Nuklir India dan Pakistan. Nation State Journal of International Studies, 1(2), 180-192. https://doi.org/10.24076/nsjis.2018v1i2.131

Farr, Bernard C. (2008). Qualitative Research Methods: A Data Collector's Field Guide. In Family Helath International (Vol. 25, pp. 1-12).

https://doi.org/10.1177/026537880802500310

Fauzi, Cahya, Sari, Suwarti, \& Rachmat, Angga Nurdin. (2016). Kepentingan Amerika Serikat Mendukung Pakistan Dalam Kasus Perebutan Wilayah Kashmir Antara India Dan Pakistan (2009-2013). Aristoteles. Retrieved from http://repository.unjani.ac.id/index.php?p=show_detail\&id=103\&keywords=

Hafiz, Khairul. (2020). Motivasi Indonesia Menandatangani Preferential Trade Agreement (PTA) dengan Pakistan Tahun 2012. Journal UNRI, 1-14. Retrieved from http://jom.unri.ac.id/index.php/JOMFSIP/article/view/2147

Hervi, Muhammad Adrindra. (2019). Pakistan's Naval Upgrading in South Asia: a Form of Bandwagoning (Airlangga University). Retrieved from http://repository.unair.ac.id/id/eprint/83471

Hibatullah, M. N., \& Nashir, A. K. (2021). Diplomasi Perdagangan Indonesia dan Pakistan Periode 2017-2019. Studi Kasus: Respon Indonesia Terhadap Rencana Kebijakan Pelarangan Vanaspati Ghee. Dauliyah Journal of Islamic and International Affairs, 6(1), 87-113.

https://doi.org/http://dx.doi.org/10.21111/dauliyah.v6i1.5585

Horne, Benjamin C. (2013). Conflict and Third Party Mediation (University of California). Retrieved from https://escholarship.org/content/qt5c70258g/qt5c70258g.pdf?t=msyi78\&v=lg

Ingpraja, Ariscynatha Putra. (2020). Diplomasi Ekonomi Indonesia dalam Meningkatkan Penetrasi Pasar Crude Palm Oil di India Melalui Penurunan Hambatan Dagang (Pertamina University). Retrieved from https://library.universitaspertamina.ac.id/xmlui/handle/123456789/861

KEMLU. (2019). Keanggotaan Tidak Tetap Indonesia pada Dewan Keamanan PBB Periode 2019-2020. Retrieved June 16, 2021, from DK PBB website: https://kemlu.go.id/portal/id/page/42/keanggotaan_indonesia_pada_dk_pbb

Khairunnisa, Brilliant Windy. (2021). The Role and Challenges of A Mediator To Resolve The International Conflict in The Digital Era ( Case Study: The Role of OANA ). Journal of Social Science, 2(5), 558-566. https://doi.org/https://doi.org/10.46799/jss.v2i5.199

Lutfiyana, Rohmah. (2018). Bollywood sebagai Instrumen Diplomasi India dalam Meredam Konflik dengan Pakistan (Universitas Wahid Hasyim). Retrieved 
from http://eprints.unwahas.ac.id/1150/

Noer Aieni, Aniesa. (2017). Pengembangan Nuklir India Dan Implikasi Terhadap Keamanan Regional Di Asia Selatan. Repository UMY, 1-21. Retrieved from http://repository.umy.ac.id/bitstream/handle/123456789/12284/k. jurnal.pdf? sequence $=11 \&$ isAllowed $=y$

Nugroho, Agung Y. (2017). Aspek Konstruktivis dalam Sengketa Wilayah Kashmir antara India dan Pakistan. Global Insight Journal, 01(02), 96-106. https://doi.org/https://doi.org/10.52447/gij.v1i2.635

Oktarezki, Alfin. (2021). KEPENTINGAN AMERIKA SERIKAT SEBAGAI MEDIATOR KRISIS DIPLOMATIK ANTARA NEGARA-NEGARA ARAB DENGAN NEGARA QATAR TAHUN 2017 (Universitas Sriwijaya). Retrieved from https://repository.unsri.ac.id/53327/

Raharjo, S. N. I. (2015). Peran Identitas Agama Dalam Konflik di Rakhine Myanmar Tahun 2012 - 2013. Jurnal Kajian Wilayah, 6(1), 35-51. https://doi.org/https://doi.org/10.14203/jkw.v6i1.68

Rasyid, Indira Endena Padanta. (2020). Kerjasama Pertahanan Indonesia-India Bagi Pengembangan Pertahanan Laut Indonesia (Universitas Pasundan). Retrieved from http://repository.unpas.ac.id/49874/

Rizky, Alfi. (2016). Pengaruh Perebutan Wilayah Kashmir Terhadap Hubungan Diplomatik India-Pakistan Periode 2011 - 2013. JOM FISIP, 3(2), 1-13.

Rosdiana, Nurul Itsna. (2020). Analisis Pencabutan Pemberlakuan Otonomi Khusus Kashmir Dan Jammu Oleh Pemerintah India. Jurnal Ilmu Sosial Dan Humaniora, 9(2), 347. https://doi.org/10.23887/jish-undiksha.v9i2.23051

Sitepu, Satria Kencana. (2017). Film Bajrangi Bhaijaan sebagai Media Diplomasi Publik India terhadap Pakistan (Universitas Lampung). Retrieved from http://digilib.unila.ac.id/27874/

Soendari, Tjutju. (2006). Pengujian Keabsahan Data Penelitian Kualitatif. In Management Penelitian Analisis (Vol. 59). Bandung.

Sudirman, Faturachman Alputra, Sarma, Wa Ode Dina, \& Susilawaty, Fera Tri. (2020). Promosi Pariwisata Melalui Digital Diplomacy: Upaya Internasionalisasi Pariwisata Daerah. Jurnal Ilmu Komunikasi UHO, 5(3), 174-185. Retrieved from http://ojs.uho.ac.id/index.php/KOMUNIKASI/article/view/12655

Sugianto, Fajar, Simeon, Felicia Christina, \& Wibowo, Dea Prasetyawati. (2020). Idealisasi Sifat Alternatif dalam Penyelesaian Sengketa Melalui Mediasi. Jurnal Hukum Bisnis Bonum Commune, 3(2), 253-265.

Suwandono, Agus. (2018). Penyelesaian Sengketa Konsumen Berbasis Kearifan 
Lokal: Peluang dan Tantangan. Jurnal Panorama Hukum, 3(2), 189-204. https://doi.org/https://doi.org/10.21067/jph.v3i2.2814

Wani, Hilal Ahmad, \& Suwirta, Andi. (2014). United Nations Involvement in Kashmir Conflict. Jurnal Kajian Sejarah \& Pendidikan Sejarah, 2(1), 41-50. https://doi.org/https://doi.org/10.2121/susurgalur.v2i1.73 